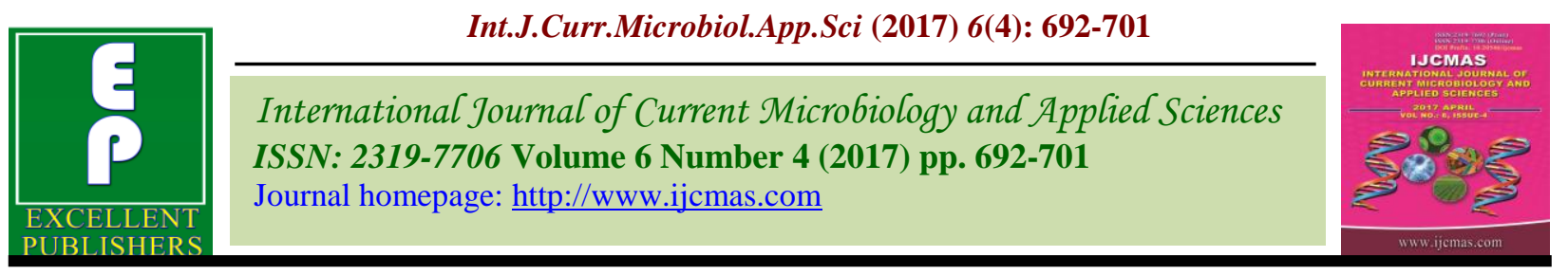

Original Research Article https://doi.org/10.20546/ijcmas.2017.604.085

\title{
Evaluation of Physical and Textural Properties of Cookies Prepared from Pearl Millet Flour
}

\author{
A.A. Kulthe*, S.S. Thorat and S.B. Lande \\ Department of Food Science and Technology, MPKV, Rahuri - 413 722, (M.S.) India \\ *Corresponding author
}

A B S T R A C T

Keywords

Cookies; Pearl millet flour; Spread factor; Spread ratio; Texture analysis.

Article Info

Accepted:

06 March 2017

Available Online:

10 April 2017
Cookies were prepared by substituting wheat maida with pearl millet flour (PMF) from three cultivars (viz. Shanti, Dhanshakti and Pioneer 84M64) at 0, 10, 20, 30, 40 and 50\% levels using traditional creamery method. Incorporation of PMF in cookies decreased diameter, spread ratio and spread factor of cookies whereas the thickness increased slightly. The colour values $L^{*}$ and $b^{*}$ decreased while $a^{*}$ increased with the addition of PMF to the cookies. The hardness, breaking strength and cutting strength of cookies were increased with the incorporation of PMF in cookies. Thus incorporation of PMF (var. Dhanshakti) in formulation of cookies was found to be superior to Shanti and Pioneer 86M64, based on physical and textural quality of cookies.

\section{Introduction}

Pearl millet (Pennisetum glaucum L) is the fourth most important cereal of India after rice, wheat and sorghum. It provides cheap staple food with comparatively more nutrients to millions of poor people, cattle and poultry (Khairwal et al., 1997). It is recognized as being the most widely grown of all the millet types. It is the basic staple food in the poorest countries and used by the poorest people. For human consumption it can be used in a variety of ways including both leavened and unleavened breads, in porridges, and can also be boiled or steamed. Due to the presence of the fibrous seed coat, the flour of pearl millet is coarse and has a grey to yellow colour which imparts bitter taste and the products prepared from whole flour have low consumer appeal (Olatungi et al., 1982). This is one reason for its poor acceptability by rice/wheat eaters.

The Indian bakery industry has important place in the industrial map of the country. Bakery products are an item of mass consumption in view of its low price and high nutritive value. Consumers demand healthier bakery products and some of the popular trends in the market are the introduction of low/light, functional, natural and organic products (Jamuna and Suresha, 2012). In addition to healthier products, consumers are also purchasing products that satisfy their taste buds. The taste enjoyment factor is vital in the market place, as the large range in bakery products available provides a wide range of consumer choice. Consumers 
increasingly seek premium and exotic products to satisfy their desire to indulge. Cakes, pastries, biscuits and cookies are the typical indulgent products within the bakery sector. Cookies are ready to eat, convenient, inexpensive and one of the most popular and widely consumed processed food products in India (Shukla and Shipla, 2000).

Cookies are now in common use in India and are preferred and loved by almost every individual irrespective of class and age. Bakery industry has a very important role to play in economic development of the country and also in building the health of people. The nutritional significance of the bakery products is well recognized. Attempts are being made to enrich the products with high quality nonwheat flours like cookies which are ready to eat, convenient, inexpensive and one of the most popular and widely consumed processed food products in India.

The present work visualizes the exploitation of pearl millet in cookies and evaluating its effect on the physical and textural properties of cookies.

\section{Materials and Methods}

\section{Materials}

Three cultivars of pearl millet viz., Shanti (RHRBH 9808), Dhanshakti (ICTP $8203 \mathrm{Fe}$ 10-2) and Pioneer 86M64 were procured from Department of Plant Breeding, College of Agriculture, Dhule, Mahatma Phule Krishi Vidyapeeth, Rahuri. The raw materials such as maida, sugar, vanaspati, sodium bicarbonate, ammonium bicarbonate, etc. were purchased from local market of Rahuri.

\section{Preparation of cookies}

Cookies were prepared using the traditional creamery method described by Whitley (1970). The ingredients included (g) wheat maida 100, sugar 50, vanaspati 50, ammonium bicarbonate 0.5 , sodium bicarbonate 0.5 , and required amount of water. Cookies were prepared by substituting wheat maida with $0,10,20,30,40$ and 50\% (w/w) PMF. The cookies were evaluated for physical and textural properties.

\section{Physical parameters}

Weight, diameter, thickness, spread ratio and $\%$ spread factor of cookies were estimated as per AACC (1976) methods.

\section{Colour values}

The colour scanning machine (Model: Colour Flex EZ) was used for the measurement of colour of cookies. The colour was measured by using CIELAB scale at $10^{\circ}$ observer at D65 illuminant. The cookies sample was placed in the sample cup and the reading in terms of $L^{*}, a^{*}$ and $b^{*}$ were measured. The deviation of the colour of the sample to standard was observed and recorded in the computer interface.

\section{Textural characteristics of cookies}

Textural characteristics of cookies such as hardness, breaking strength and cutting strength of cookies were measured using Instron Universal Texturometer (Shimadzu AG-Xplus). Each cookie was placed on the loading cell and compressed as per the standard procedures given by Singh et al., (1993).

\section{Statistical analysis}

The data obtained was analyzed statistically to determine statistical significance of treatments. Completely Randomized Design (CRD) was used to test the significance of results (Panse and Sukhatme, 1967). The analysis of variance revealed at significance of $\mathrm{p}<0.05$ level, S.E. and C.D. at $5 \%$ level was mentioned wherever required. 


\section{Results and Discussion}

The cookies were prepared by substituting maida with PMF of each variety viz., Shanti, Dhanshakti and Pioneer 86M64 at levels of 10, 20, 30, 40 and 50 per cent. The cookies were evaluated for their physical and textural characteristics and results are presented below.

\section{Physical properties of pearl millet incorporated cookies}

The data regarding physical properties such as weight, diameter, thickness, spread ratio, and spread factor of cookies is presented in table 1. It was observed that the weight of cookies decreased gradually from 9.97 to $9.54 \mathrm{~g}$ with increasing proportion of PMF. Also there was simultaneous decrease in diameter from 49.40 to $44.66 \mathrm{~mm}$. No trend was observed for thickness of cookies because the baking was not performed under strict conditions of temperature and humidity.

The spread ratio of cookies firstly increased from 3.71 to 5.05 and then decreased significantly from 5.05 to 3.44 with increasing level of PMF. The spread factor of cookies too showed similar trend. The spread factor of control sample was considered as standard (100\%). In comparison to control sample, there was initial increase in spread factor of cookies with $10 \% \mathrm{PMF}$. This initial increase in spread ratio might be due to the combined effect of sugar and fibres in the dough. In cookies containing $10 \%$ PMF, the high sugar and low fibre content resulted in increased diameter and reduced thickness of cookies during baking. Among the PMF based samples, the spread factor significantly decreased from 136.50 to $92.97 \%$ with increased addition of PMF. But since the spread factor of cookies with PMF up to $40 \%$ was comparable as that of control sample, the substitution level of $40 \%$ was considered to be optimized. The previous studies (MaacheRezzoug et al., 1998) showed positive correlation between sugar content and diameter of biscuits; the greater the quantity of sugar, the greater increase in the biscuit length, with considerable decrease in thickness when sogar content was increased. As the level of PMF increased there was increase in the more water absorbing fibre content compared to sugar content. Increase in fibre content retarded the spreading of cookies thus reducing the diameter with subsequent increase in thickness of cookies (Agrahar-Murugkar et al., 2014).

Among PMF varieties (Table 1), Dhanshakti PMF based cookies recorded highest spread ratio (4.32) and spread factor (116.76 \%) as compared to control and other samples. Reduced spread ratio and spread factor of cookies were attributed to the fact that composite flours of wheat and PMF apparently form aggregates with increased number of hydrophilic sites available for competing, for the limited free water in dough (McWatters, 1978). Rapid partitioning of free water of these hydrophilic sites occurs during dough mixing and increases dough viscosity, thereby limiting the cookie spread (AgraharMurugkar et al., 2014). Also gluten influenced the diameter and spread onset time which is again dependent on the amount free water available to the non-gluten constituents (Bram et al., 2008).

\section{Colour of pearl millet based cookies}

Colour appears to be the important element for initial acceptability of baked product by consumers. Moreover, as colour development occurs largely during the later stages of baking (Wade, 1988), it can be used to judge completion of the baking process. Cookies incorporated with PMF were evaluated for their colour values in terms of $L^{*}, a^{*}, b^{*}, C^{*}$ and $H^{*}$. 
The level of substitution as well as variety of pearl millet both affected the colour values i.e. $L^{*}, a^{*}$ and $b^{*}$ of cookies (Table 2). The values $L^{*}$ and $b^{*}$ decreased from 74.347 to 55.351 and from 21.143 to 16.314 , respectively where as $a *$ increased from 1.220 to 3.633 with increasing level of PMF.

The colour values of control samples; $L^{*}, a^{*}$, $b^{*}, C^{*}$ and $H^{*}$ were observed as $74.347,1.22$, 21.143, 21.178 and 86.663, respectively. The colour values $\left(L^{*}, a^{*}\right.$ and $\left.b^{*}\right)$ of cookies with different PMF varieties viz., Shanti (62.171, 2.865, 18.351, 18.609 and 81.017), Dhanshakti (63.113, 2.920, 18.673, 18.927 and 80.918) and Pioneer 86M64 (61.190, $2.933,18.162,18.278$ and 80.239) were recorded and among the different varieties, the Dhanshakti PMF incorporated cookies showed good colour values.

Colour development of baked products is caused by Maillard reactions between sugars and proteins (Lingnert, 1990). The Maillard reaction is a non-enzymatic reaction which causes the formation of melanoidins. Others factors that might contribute to the colour of final products were ingredients' composition, time of baking (Cronin and Preis, 2000). The humidity in the oven and atmosphere in the early stages of baking also affected the development of final colour (Wade, 1988). Pearl millet cookies were dark and fragile as compared to control samples prepared from maida alone. The darkness of cookies increased with the increase in the proportion of PMF from 10 to 50 per cent. Significant difference $(p<0.05)$ was found in the color parameters for cookies obtained from all treatments. The $L^{*}$ value of all PMF based cookies were lower than control sample indicating darker color due to the nature of ingredients. The positive $a^{*}$ value represents redness of PMF cookies. A positive $b^{*}$ value is a measure of the yellowness and the low $b^{*}$ values indicated darkness of cookies prepared with incorporation of PMF.
Pearl millet has polyphenol oxidase and peroxidase activities (Prabha and Patwardhan, 1982; Saby John et al., 2003) and they are rich in polyphenols, which are substrates for these enzymes (Ajila et al., 2007; Saby John et al., 2003). Therefore, due to the enzymatic browning, brightness and yellowness of the cookies may be decreased (Ajila et al., 2008). Also, as PMF has greenish colour, incorporation of PMF with wheat flour also decreased the brightness of the cookies.

\section{Textural characteristics of PMF incorporated cookies}

Texture is a very important characteristic which makes a significant contribution to the overall acceptance of food products. It is one of the three main acceptability factors used by consumers to evaluate food, the other two being appearance and flavor (Bourne, 1990). The results with respect to textural characteristics of cookies like hardness, breaking strength, cutting strength and energy are presented in table 3.

The average peak force is the measure of cookies hardness. It was observed that there was significant increase in hardness of cookies from 3.76 to $15.97 \mathrm{~N}$ with increasing levels of PMF in cookies. The increased hardness may be attributed to dilution of wheat proteins with pearl millet proteins. The interaction of pearl millet proteins with wheat proteins made cookies compact, thus increasing the hardness.

Hoseney and Rogers (1994) reported that hardness of cookies is caused by the interaction of protein and starch by hydrogen bonding. Similar results were observed by Singh et al., (1996) who reported increased hardness in biscuits with increasing levels of DSF up to 50 per cent. 
Table.1 Physical parameters of cookies affected by pearl millet variety and treatments

\begin{tabular}{|c|c|c|c|c|c|c|c|c|c|c|c|c|c|c|c|c|c|c|c|c|}
\hline \multirow{2}{*}{ Treatments } & \multicolumn{4}{|c|}{ Weight (g) } & \multicolumn{4}{|c|}{ Diameter (mm) } & \multicolumn{4}{|c|}{ Thickness (mm) } & \multicolumn{4}{|c|}{ Spread Ratio } & \multicolumn{4}{|c|}{ Spread Factor $(\%)$} \\
\hline & $\mathbf{V}_{1}$ & $\mathbf{V}_{2}$ & $\mathbf{V}_{3}$ & Mean & $\mathrm{V}_{1}$ & $\mathbf{V}_{2}$ & $\mathbf{V}_{3}$ & Mean & $\mathbf{V}_{1}$ & $\mathbf{V}_{2}$ & $\mathbf{V}_{3}$ & Mean & $\mathbf{V}_{1}$ & $\mathbf{V}_{2}$ & $\mathbf{V}_{3}$ & Mean & $\mathbf{V}_{1}$ & $\mathbf{V}_{2}$ & $\mathbf{V}_{3}$ & Mean \\
\hline $\mathbf{T}_{\mathbf{0}}$ & 9.97 & 9.97 & 9.97 & 9.97 & 49.40 & 49.40 & 49.40 & 49.40 & 13.33 & 13.33 & 13.33 & 13.33 & 3.71 & 3.71 & 3.71 & 3.71 & 100.00 & 100.00 & 100.00 & 100.00 \\
\hline $\mathbf{T}_{1}$ & 9.90 & 9.94 & 9.85 & 9.90 & 49.67 & 50.00 & 49.43 & 49.70 & 10.00 & 9.40 & 10.17 & 9.86 & 4.97 & 5.32 & 4.86 & 5.05 & 134.05 & 143.57 & 131.24 & 136.50 \\
\hline $\mathbf{T}_{2}$ & 9.83 & 9.86 & 9.80 & 9.83 & 48.17 & 48.53 & 47.37 & 48.02 & 10.33 & 10.20 & 10.97 & 10.50 & 4.66 & 4.95 & 4.32 & 4.59 & 125.81 & 133.67 & 116.58 & 124.11 \\
\hline $\mathbf{T}_{3}$ & 9.72 & 9.78 & 9.68 & 9.73 & 47.07 & 47.57 & 46.27 & 46.97 & 11.80 & 10.60 & 12.00 & 11.47 & 3.99 & 4.49 & 3.86 & 4.13 & 107.66 & 121.12 & 104.06 & 111.52 \\
\hline $\mathbf{T}_{4}$ & 9.59 & 9.71 & 9.53 & 9.61 & 45.93 & 46.37 & 45.73 & 46.01 & 12.67 & 11.37 & 12.77 & 12.27 & 3.63 & 4.08 & 3.58 & 3.78 & 97.88 & 110.10 & 96.69 & 102.07 \\
\hline $\mathbf{T}_{5}$ & 9.52 & 9.64 & 9.47 & 9.54 & 44.60 & 45.30 & 44.07 & 44.66 & 13.00 & 13.00 & 13.10 & 13.03 & 3.43 & 3.48 & 3.36 & 3.44 & 92.60 & 94.05 & 90.79 & 92.97 \\
\hline \multirow[t]{2}{*}{ Mean } & 9.76 & 9.82 & 9.72 & & 47.47 & 47.86 & 47.04 & & 11.86 & 11.32 & 12.06 & & 4.07 & 4.32 & 3.96 & & 109.77 & 116.76 & 107.06 & \\
\hline & \multicolumn{2}{|c|}{ SEm \pm} & \multicolumn{2}{|c|}{ CD at $5 \%$} & \multicolumn{2}{|c|}{ SEm \pm} & \multicolumn{2}{|c|}{ CD at $5 \%$} & \multicolumn{2}{|c|}{ SEm \pm} & \multicolumn{2}{|c|}{ CD at $5 \%$} & \multicolumn{2}{|c|}{ SEm \pm} & \multicolumn{2}{|c|}{ CD at $5 \%$} & \multicolumn{2}{|c|}{ SEm \pm} & \multicolumn{2}{|c|}{ CD at $5 \%$} \\
\hline Treatment (T) & \multicolumn{2}{|c|}{0.033} & \multicolumn{2}{|c|}{0.096} & \multicolumn{2}{|c|}{0.028} & \multicolumn{2}{|c|}{0.080} & \multicolumn{2}{|c|}{0.028} & \multicolumn{2}{|c|}{0.081} & \multicolumn{2}{|c|}{0.092} & \multicolumn{2}{|c|}{0.264} & \multicolumn{2}{|c|}{3.088} & \multicolumn{2}{|c|}{8.892} \\
\hline Variety (V) & \multicolumn{2}{|c|}{0.024} & \multicolumn{2}{|c|}{0.068} & \multicolumn{2}{|c|}{0.020} & \multicolumn{2}{|c|}{0.057} & \multicolumn{2}{|c|}{0.020} & 0.0 & & & & 0. & 87 & & & & \\
\hline $\mathbf{T} \times \mathbf{V}$ & & & & 70 & & & 0.1 & & & & 0.1 & & & & & 59 & & & & \\
\hline
\end{tabular}

Each value is the average of three determinations

$\mathrm{V}_{1^{-}}$Shanti, $\mathrm{V}_{2^{-}}$Dhanshakti, $\mathrm{V}_{3^{-}}$Pioneer 86M64 
Table.2 Influence of treatments and pearl millet variety on colour values of cookies

\begin{tabular}{|c|c|c|c|c|c|c|c|c|c|c|c|c|c|c|c|c|c|c|c|c|}
\hline \multirow{2}{*}{$\begin{array}{c}\text { Treatme } \\
\text { nts }\end{array}$} & \multicolumn{4}{|c|}{$L^{*}$} & \multicolumn{4}{|c|}{$a^{*}$} & \multicolumn{4}{|c|}{$b^{*}$} & \multicolumn{4}{|c|}{$C^{*}$} & \multicolumn{4}{|c|}{$H^{*}$} \\
\hline & $\mathbf{V}_{1}$ & $\mathbf{V}_{2}$ & $\mathbf{V}_{3}$ & Mean & $\mathbf{V}_{1}$ & $\mathbf{V}_{2}$ & $\mathbf{V}_{3}$ & Mean & $\mathbf{V}_{1}$ & $\mathbf{V}_{2}$ & $\mathbf{V}_{3}$ & Mean & $\mathbf{V}_{1}$ & $\mathbf{V}_{2}$ & $\mathbf{V}_{3}$ & Mean & $\mathbf{V}_{1}$ & $\mathbf{V}_{2}$ & $\mathbf{V}_{3}$ & Mean \\
\hline \multirow{2}{*}{$\mathbf{T}_{\mathbf{0}}$} & 74.3 & 74.3 & 74.3 & 74.3 & 1.2 & 1.2 & 1.2 & 1.2 & 21.1 & 21.1 & 21.1 & 21.1 & 21.1 & 21.1 & 21.1 & 21.1 & 86.6 & 86.6 & 86.6 & 86.6 \\
\hline & 47 & 47 & 47 & 47 & 20 & 20 & 20 & 20 & 43 & 43 & 43 & 43 & 78 & 78 & 78 & 78 & 63 & 63 & 63 & 63 \\
\hline \multirow{2}{*}{$\mathbf{T}_{1}$} & 65.6 & 66.8 & 62.9 & 65.1 & 2.0 & 2.5 & 2.6 & 2.4 & 18.7 & 20.3 & 18.6 & 19.2 & 18.8 & 20.5 & 18.8 & 19.4 & 83.7 & 82.6 & 82.0 & 82.9 \\
\hline & 60 & 66 & 37 & 54 & 33 & 97 & 09 & 13 & 60 & 55 & 47 & 54 & 70 & 20 & 29 & 06 & 81 & 96 & 02 & 37 \\
\hline \multirow{2}{*}{$\mathbf{T}_{2}$} & 60.4 & 62.2 & 59.8 & 60.8 & 2.5 & 3.4 & 2.6 & 2.8 & 17.3 & 18.7 & 17.7 & 17.9 & 17.5 & 19.0 & 18.1 & 18.2 & 81.5 & 79.5 & 78.2 & 79.7 \\
\hline & 17 & 71 & 00 & 29 & 76 & 33 & 81 & 97 & 59 & 48 & 83 & 63 & 49 & 60 & 60 & 56 & 26 & 91 & 74 & 97 \\
\hline \multirow{2}{*}{$\mathbf{T}_{3}$} & 58.9 & 60.6 & 58.4 & 59.3 & 3.7 & 3.5 & 3.4 & 3.5 & 17.7 & 17.7 & 17.6 & 17.7 & 18.1 & 18.0 & 16.9 & 17.7 & 78.1 & 78.7 & 80.1 & 79.0 \\
\hline & 52 & 95 & 66 & 71 & 12 & 03 & 38 & 50 & 40 & 32 & 73 & 15 & 24 & 75 & 20 & 06 & 50 & 93 & 64 & 36 \\
\hline \multirow{2}{*}{$\mathbf{T}_{4}$} & 58.0 & 58.7 & 56.8 & 57.8 & 3.9 & 3.3 & 3.8 & 3.7 & 18.5 & 17.7 & 17.6 & 17.9 & 19.0 & 18.0 & 18.0 & 18.3 & 77.9 & 79.1 & 77.7 & 78.3 \\
\hline & 84 & 10 & 89 & 94 & 57 & 93 & 17 & 22 & 89 & 08 & 52 & 83 & 05 & 30 & 60 & 65 & 52 & 21 & 67 & 91 \\
\hline \multirow{2}{*}{$\mathbf{T}_{5}$} & 55.5 & 55.7 & 54.7 & 55.3 & 3.6 & 3.3 & 3.8 & 3.6 & 16.5 & 16.3 & 16.0 & 16.3 & 16.9 & 16.6 & 16.5 & 16.7 & 77.3 & 78.3 & 76.5 & 77.5 \\
\hline & 66 & 87 & 00 & 51 & 94 & 73 & 30 & 33 & 17 & 52 & 72 & 14 & 25 & 96 & 22 & 14 & 62 & 13 & 65 & 24 \\
\hline \multirow[t]{2}{*}{ Mean } & $\begin{array}{c}62.1 \\
71\end{array}$ & $\begin{array}{c}63.1 \\
13\end{array}$ & $\begin{array}{c}61.1 \\
90\end{array}$ & & $\begin{array}{l}2.8 \\
65\end{array}$ & $\begin{array}{l}2.9 \\
20\end{array}$ & $\begin{array}{l}2.9 \\
33\end{array}$ & & $\begin{array}{c}18.3 \\
51\end{array}$ & $\begin{array}{c}18.6 \\
73\end{array}$ & $\begin{array}{c}18.1 \\
62\end{array}$ & & $\begin{array}{c}18.6 \\
09\end{array}$ & $\begin{array}{c}18.9 \\
27\end{array}$ & $\begin{array}{c}18.2 \\
78\end{array}$ & & $\begin{array}{c}81.0 \\
17\end{array}$ & $\begin{array}{c}80.9 \\
18\end{array}$ & $\begin{array}{c}80.2 \\
39\end{array}$ & \\
\hline & \multicolumn{2}{|c|}{ SEm \pm} & \multicolumn{2}{|c|}{ CD at $5 \%$} & \multicolumn{2}{|c|}{ SEm \pm} & \multicolumn{2}{|c|}{ CD at $5 \%$} & \multicolumn{2}{|c|}{ SEm \pm} & \multicolumn{2}{|c|}{ CD at $5 \%$} & \multicolumn{2}{|c|}{ SEm \pm} & \multicolumn{2}{|c|}{ CD at $5 \%$} & \multicolumn{2}{|c|}{ SEm \pm} & \multicolumn{2}{|c|}{ CD at $5 \%$} \\
\hline $\begin{array}{c}\text { Treatment } \\
\text { (T) }\end{array}$ & \multicolumn{2}{|c|}{0.741} & \multicolumn{2}{|c|}{3.135} & \multicolumn{2}{|c|}{0.010} & \multicolumn{2}{|c|}{0.028} & \multicolumn{2}{|c|}{0.716} & \multicolumn{2}{|c|}{2.061} & & & 1.5 & 946 & & & & 704 \\
\hline $\begin{array}{c}\text { Variety } \\
\text { (V) }\end{array}$ & 0.5 & & & 509 & & & & 020 & 0.5 & & & 516 & & & 1.4 & 431 & & & & 725 \\
\hline $\mathbf{T} \times \mathbf{V}$ & 1.2 & & & JS & & & & 048 & 1.2 & & & JS & & & $\mathrm{N}$ & JS & & & & IS \\
\hline
\end{tabular}

Each value is the average of three determinations

$\mathrm{V}_{1}$ - Shanti, $\mathrm{V}_{2}$ - Dhanshakti, $\mathrm{V}_{3}$ - Pioneer 86M64 
Table.3 Effect of treatments and pearl millet variety on textural characteristics of cookies

\begin{tabular}{|c|c|c|c|c|c|c|c|c|c|c|c|c|}
\hline \multirow{2}{*}{ Treatments } & \multicolumn{4}{|c|}{ Hardness (N) } & \multicolumn{4}{|c|}{ Breaking Strength $(\mathbf{N})$} & \multicolumn{4}{|c|}{ Cutting Strength (N) } \\
\hline & $\mathbf{V}_{1}$ & $\mathbf{V}_{2}$ & $\mathbf{V}_{3}$ & Mean & $\mathbf{V}_{1}$ & $\mathbf{V}_{2}$ & $\mathbf{V}_{3}$ & Mean & $\mathbf{V}_{1}$ & $\mathbf{V}_{2}$ & $\mathbf{V}_{3}$ & Mean \\
\hline $\mathbf{T}_{\mathbf{0}}$ & 3.76 & 3.76 & 3.76 & 3.76 & 29.78 & 29.78 & 29.78 & 29.78 & 30.39 & 30.39 & 30.39 & 30.39 \\
\hline $\mathbf{T}_{1}$ & 6.61 & 5.18 & 6.95 & 6.25 & 34.13 & 30.39 & 35.33 & 33.28 & 35.47 & 31.22 & 37.35 & 34.68 \\
\hline $\mathbf{T}_{2}$ & 8.81 & 7.67 & 8.93 & 8.47 & 37.48 & 34.16 & 37.86 & 36.50 & 38.56 & 35.68 & 39.49 & 37.91 \\
\hline $\mathbf{T}_{3}$ & 11.57 & 9.26 & 12.69 & 11.17 & 40.13 & 35.68 & 40.33 & 38.71 & 40.50 & 37.48 & 41.05 & 39.68 \\
\hline $\mathbf{T}_{4}$ & 13.46 & 11.58 & 14.82 & 13.29 & 41.57 & 38.97 & 41.67 & 40.74 & 42.71 & 40.16 & 43.75 & 42.21 \\
\hline $\mathbf{T}_{5}$ & 16.67 & 13.86 & 17.39 & 15.97 & 44.63 & 39.48 & 44.89 & 43.00 & 44.30 & 41.64 & 45.22 & 43.72 \\
\hline \multirow[t]{2}{*}{ Mean } & 10.15 & 8.55 & 10.76 & & 37.95 & 34.74 & 38.31 & & 38.66 & 36.09 & 39.54 & \\
\hline & \multicolumn{2}{|c|}{ SEm \pm} & \multicolumn{2}{|c|}{ CD at $5 \%$} & \multicolumn{2}{|c|}{ SEm \pm} & \multicolumn{2}{|c|}{ CD at $5 \%$} & \multicolumn{2}{|c|}{ SEm \pm} & \multicolumn{2}{|c|}{ CD at $5 \%$} \\
\hline Treatment $(T)$ & \multicolumn{2}{|c|}{0.016} & \multicolumn{2}{|c|}{0.046} & \multicolumn{2}{|c|}{0.017} & \multicolumn{2}{|c|}{0.048} & \multicolumn{2}{|c|}{1.361} & \multicolumn{2}{|c|}{3.919} \\
\hline Variety (V) & \multicolumn{2}{|c|}{0.011} & \multicolumn{2}{|c|}{0.033} & \multicolumn{2}{|c|}{0.012} & \multicolumn{2}{|c|}{0.034} & \multicolumn{2}{|c|}{0.962} & \multicolumn{2}{|c|}{ NS } \\
\hline $\mathbf{T} \times \mathbf{V}$ & \multicolumn{2}{|c|}{0.028} & \multicolumn{2}{|c|}{0.080} & \multicolumn{2}{|c|}{0.029} & \multicolumn{2}{|c|}{0.083} & \multicolumn{2}{|c|}{2.357} & \multicolumn{2}{|c|}{ NS } \\
\hline
\end{tabular}

Each value is the average of three determinations

$\mathrm{V}_{1}$ - Shanti, $\mathrm{V}_{2}$ - Dhanshakti, $\mathrm{V}_{3}$ - Pioneer 86M64 
Gandhi et al., (2001) also reported increased hardness of cookies prepared by replacing wheat flour up to $40 \%$ level with DSF. Krishnan et al., (2011) also reported increase in the hardness of biscuits prepared from finger millet seed coat based composite flour.

The breaking strength is also one of the criteria to measure the cookies hardness. The results indicated that the breaking strength of cookies significantly increased from 29.78 to $43.00 \mathrm{~N}$ with increasing levels of PMF in cookies. Sugar may recrystallise during cooling or product storage as water is removed during baking, creating a supersaturated sucrose solution in the cookies. Earlier research showed that sugar crystallization and formation of a glassy solid after baking would influence hardness of biscuit (Gaines et al., 1992; Slade and Levine, 1994; Slade et al., 1993) Recently, Sudha et al., (2007) reported a decrease in diameter and increase in breaking strength of biscuits upon addition of cereal bran and decrease in thickness upon addition of barley bran.

In the cutting test, the probe cut the cookie right through and the resulting graph had a cuspidate (elephant tusk) profile, resulting from the progressive increasing force during cutting. The maximum peak was registered at about $2 \mathrm{~mm}$ from the start of cutting, after that there was drastic force loss. The residual force registered was due to the friction of blade passing through the cookies. The cutting strength of cookies showed similar trend for hardness and breaking strength of cookies. The cutting strength of cookies increased from 30.39 to $43.72 \mathrm{~N}$ with increasing levels of PMF in cookies. The increase in cutting strength of cookies may be due to relatively higher water content in PMF incorporated doughs. It is reported that doughs having higher water content produce an extensive gluten structure and result in harder cookies (Gaines, 1990; Labuschagne et al., 1996; Smith, 1972).
Among PMF varieties, Pioneer 86M64 recorded the highest increase in hardness $(10.76 \mathrm{~N})$, breaking strength $(38.31 \mathrm{~N})$, cutting strength $(39.54 \mathrm{~N})$ and energy $(0.037$ J) followed by cookie with Shanti PMF recording intermediate values $(10.15 \mathrm{~N}, 37.95$ $\mathrm{N}, 38.66 \mathrm{~N}$ and $0.036 \mathrm{~J}$ respectively), while Dhanshakti showed lowest increase in textural characteristics $(8.55 \mathrm{~N}, 34.74 \mathrm{~N}$, $36.09 \mathrm{~N}$ and $0.030 \mathrm{~J}$, respectively) of cookies. This may be attributed to the difference in the chemical composition of PMF.

In a previous study of semi-sweet biscuit production with different varieties, it was observed that, for some varieties, a weakening in dough strength reduced biscuit hardness, but that for other varieties the hardness of biscuits was unaffected by changes in dough strength (Oliver et al., 1995). The results are agreement with the earlier report.

In conclusion the results of this study indicate that, the physical and textural characteristics of cookies were affected by different levels and varieties of PMF. Incorporation of PMF in cookies spread ratio and spread factor of cookies. Cookies with PMF were dark in colour as compared to control sample prepared from maida alone. Good quality cookies can be prepared by substituting maida with pearl millet flour up to $40 \%$. Dhanshakti variety found to be better for cookie making in comparison to Shanti and Pioneer 86M64 with respect to physical and textural properties of cookies.

\section{References}

AACC. 1976. American Association of Cereal Chemists, $7^{\text {th }}$ Edn.

AOAC. 1995. Official Methods of Analysis $15^{\text {th }}$ Edn., Association of Official Analytical Chemists, Washington DC.

AOAC. 1990. Official Methods of Analysis $15^{\text {th }}$ Edn., Association of Official 
Analytical Chemists, Washington D.C.

AOAC. 2005. Official Methods of Analysis $18^{\text {th }}$ Edn., Association of Official Analytical Chemists, Washington D.C.

Agrahar-Murugkar, D., Gulati, P., Kotwaliwale, N. and Gupta, C. 2014. Evaluation of nutritional, textural and particle size characteristics of dough and biscuits made from composite flours containing sprouted and malted ingredients. J. Food Sci. Technol., DOI: 10.1007/s13197-014-1597-y

Ajila, C.M., Bhat, S.G. and Prasada Rao, U.J.S. 2007. Valuable components of raw and ripe peels from two Indian mango varieties. Food Chem., 102: 1006-1011.

Ajila, C.M., Leelavathi, K. and Prasada Rao, U.J.S. 2008. Improvement of dietary fiber content and antioxidant properties in soft dough biscuits with the incorporation of mango peel powder. $J$. Cereal Sci., 48: 319-326.

Bram, P., Edith, W., Hans, G., Kristof, B. and Jan, A. D. 2008. The role of gluten in a sugar-snap cookie system: A model approach based on gluten-starch blends. J. Cereal Sci., 48: 863-869.

Cronin, K. and Preis, C. 2000. A statistical analysis of biscuit physical properties as affected by baking. J. Food Engg., 46(4): 217-225.

Florence, S.P., Asna, U., Asha, M.R. and Jyotsna, R. 2014. Sensory, physical and nutritional qualities of cookies prepared from pearl millet (Pennisetum typhoideum). J. Food Process. Technol., 5(10): 377, DOI: 10.4172/21577110.1000377.

Gaines, C.S. 1990. Influence of chemical and physical modification of soft wheat protein on sugar-snap cookie dough consistency, cookie size, and hardness. Cereal Chem. 67(1): 73-77.

Gaines, C.S., Kassuba, A. and Finney, P.L. 1992. Insrtumental measurement of cookie hardness. I. Assesment of methods. Cereal Chem., 62(2): 115-119. Gandhi, A.P., Kotwaliwale, N., Kawalkar, J., Shrivastava, D.C., Parihar, V.S. and Raghunadh, P. 2001. Effect of incorporation of defatted soyflour on the quality of sweet biscuits. Ad-hock Project on Alternate Solvent, Soybean Processing and Utilization Centre, Central Institute of Agricultural Engineering, Bhopal - 462038, India.

Jamuna, K.V. and Suresha, S.V. 2012. An overvirw of the bakery industry in India. Food Marketing Technol., 3(9): 40-42.

Krishnan, R., Dharmaraj, U., Manohar, R.S. and Malleshi, N.G. 2011. Quality characteristics of biscuits prepared from finger millet seed coat based composite flour. Food Chem., 129: 499-506.

Labuschagne, M.T., Brooks Coetzee, M.C. and van Deventer. 1996. Biscuit-making quality prediction using heritability estimates and correlations. J. Sci. Food Agric., 70: 25-28.

Lingnert, H. 1990. Development of the Maillard reaction during food processing. In P. A. Finot (Ed.) Maillard reaction in food processing, Human Nutri. Physiol., (pp: 171). Basel: Birkhauser Verlag.

Maache-Rezzoug, Z., Bouvier, J.M., Alla, K. and Patras, C. 1998. Effect of principal ingredients on rheological behaviour of biscuit dough and on quality of biscuits. J. Food Engg., 35: 23-42.

McWatters, K.H. 1978. Cookie baking properties of defatted peanut, soybean and field pea flour. Cereal Chem., 55(6): 853-863.

Mepba, H.D., Eboh, L. and Nwaojigwa, S.U. 2007. Chemical composition, functional and baking properties of wheat-plantain composite flours. Afr. J. Food Agric. Nutr. Dev., 7(1): 1-22. 
Olatungi, O., Akinrele, I.A., Erwards, C.C., and Loleoso, O.A. 1982. Sorghum and millets processing and uses in Nigeria. Cereal Foods World, 27: 277-280

Oliver, G., Thacker, D. and Wheeler, R.J. 1995. Semi-sweet biscuits. 1: The influence of sodium metabisulphite on dough rheology and baking performance. J. Sci. Food Agric., 69: 141-150.

Oluwamukomi, M.O., Oliwalana, I.B. and Akinbowale, O.F. 2011. Physicochemical and sensory properties of wheat-cassava composite biscuit enriched with soy flour. Afr. J. Food Sci., 5(2): 50-56.

Panse, V.S. and Sukhatme, P.V. 1967. Statistical Methods for Agricultural Workers. Indian Council of Agri. Res., New Delhi. pp: 70-72.

Prabha, T.N. and Patwardhan, M.V. 1982. Purification and properties of polyphenol oxidase of mango peel. $J$. Biosci., 4: 69-78.

Shukla, F.C. and Shilpa, M. 2000. Bakery industry in India. Present quality control and future scenario-A review. Bev. Food World, 27: 11-15.

Singh, B., Bajaj, M., Kaur, A., Sharma, S. and Sidhu, J. 1993. Studies on development of high protein biscuits from composite flours. Plant Foods Human Nutr., 43(2): 181-189.

Singh, R., Singh, G. and Chauhan, G.S. 1996. Effect of incorporation of defatted soy flour on quality of biscuits. J. Food Sci. Technol., 33(4): 355-357.

Slade, L. and Levine, H. 1994. Structurefunction relationship of cookie and cracker ingredients. In H. Faridi (Ed.). The science of cookie and cracker production (pp: 23-141). New York: Chapman and Hall.

Slade, L., Levine, H., Ievolella, J. and Wang, M. 1993. The glassy state phenomenon in applications for the food industry. Application of the food polymer science approach to structure-function relationships of sucrose in cookie and cracker systems. J. Sci. Food Agric., 63: 133-176.

Smith, W.H. 1972. Hard semi-sweet biscuits. In: Biscuits, Crackers and Cookies: Technology, Production and Management, vol. 1. Applied Science publishers Ltd., London, pp: 466-473.

Snedecor, C.W. and Cochran, W.G. 1967. Statistical Methods, $6^{\text {th }}$ Edn., Oxford and IBH Publishing Co., New Delhi.

Sudha, M.L., Vetrimani, R. and Leelavathi, K. 2007. Influence of fibre from different cereals on the rheological characteristics of wheat flour dough and on biscuit quality. Food Chem., 100: 1365-1370.

Wade, P. 1988. Biscuit, Cookies and Crackers: The Principles of the Craft. $\left(1^{\text {st }}\right.$ Edn.) London, UK: Elsevier Applied Sciences.

\section{How to cite this article:}

Kulthe, A.A., S.S. Thorat and Lande, S.B. 2017. Evaluation of Physical and Textural Properties of Cookies Prepared from Pearl Millet Flour. Int.J.Curr.Microbiol.App.Sci. 6(4): 692-701. doi: https://doi.org/10.20546/ijcmas.2017.604.085 